\title{
The Impact of Distance Learning Implementation in Early Childhood Education Teacher Profesional Competence
}

\author{
Andrisyah ${ }^{1}$, Asih Nur Ismiatun ${ }^{2 凶}$ \\ Pendidikan Guru Pendidikan Anak Usia Dini, Institut Keguruan dan Ilmu Pendidikan \\ Siliwangi \\ DOI: 10.31004/obsesi.v5i2.1009
}

\begin{abstract}
Covid-19 pandemic has an impact on early childhood education. This presents a major challenge for Early Childhood Education educators to improve their professional competence so that they can adapt to conditions in the current Covid-19 pandemic and respond to challenges in the era of society 5.0. The purpose of this study was to analyze the impact of distance learning on ECE teachers' professional competencies. Sampling used cluster sampling techniques. This study involved 30 ECE teachers from three provinces on the island of Java. The method used is descriptive qualitative. Data collection techniques used open questionnaires containing indicators of ECE teacher's professional competencies. The results showed that 30 ECE teachers in three provinces increased their professional competence especially in the use of technology that supports distance learning. support from government and institutions, is needed in improving teacher professional competence in the form of training that can reach all ECE teachers in Indonesia as a step towards facing the era of society 5.0.
\end{abstract}

Keywords: distance learning; professional competence; early childhood education teachers

\begin{abstract}
Abstrak
Pandemi Covid-19 berdampak pada pendidikan anak usia dini. Hal ini menjadi tantangan besar bagi para guru PAUD untuk meningkatkan kompetensi profesionalnya agar dapat beradaptasi dengan kondisi pandemi Covid-19 saat ini dan menjawab tantangan di era society 5.0. Tujuan dari penelitian ini adalah untuk menganalisis dampak pembelajaran jarak jauh terhadap kompetensi profesional guru PAUD. Pengambilan sampel menggunakan teknik cluster sampling. Studi ini melibatkan 30 guru PAUD dari tiga provinsi di pulau Jawa. Metode yang digunakan adalah deskriptif kualitatif. Teknik pengumpulan data menggunakan angket terbuka yang berisi indikator kompetensi profesional guru PAUD. Hasil penelitian menunjukkan bahwa 30 guru PAUD di tiga provinsi meningkat kompetensi profesionalnya terutama dalam penggunaan teknologi yang mendukung pembelajaran jarak jauh. Dukungan dari pemerintah dan lembaga, diperlukan dalam peningkatan kompetensi profesional guru dalam bentuk pelatihan yang dapat menjangkau seluruh guru PAUD di Indonesia sebagai langkah menghadapi era society 5.0.
\end{abstract}

Kata Kunci: pembelajaran jarak jauh; kompetensi profesional; guru paud

Copyright (c) 2021 Andrisyah, Asih Nur Ismiatun

$\triangle$ Corresponding author :

Email Address: asihnur@ikipsiliwangi.ac.id (Bandung, Indonesia)

Received 28 December 2020, Accepted 12 January 2021, Published 20 January 2021 


\section{INTRODUCTION}

The success of education can not be separated from the role of a teacher. The role of the teacher is significant as the spearhead of education, curriculum implementers, and education practitioners who are directly in contact with students (Fathoni, Sukirman, and Riyana, 2010). Teachers can be said to be professional when the results of their performance are good, the students being taught are able to understand what the teacher says and complete the learning process well (Jajat Sudrajat, 2020). The Covid-19 pandemic that occurred in Indonesia since March 2020 had an impact on various fields of life, one of which was education. During the Covid-19 pandemic, learning between teachers and students cannot be carried out face-to-face, so the alternative is to carry out distance learning. Distance education is a learning process that can be done from home where students and teachers are physically far away or where students are not always physically present at school (Sadeghi, 2019). Distance learning is a teaching approach, where students are not always physically present at school (Kaplan and Haenlein, 2016). The basic definition of distance learning positions teachers and students apart in spatial dimensions and that this distance is filled by using technological resources (Casarotti et al., 2002). Distance learning increases access to learning and training opportunities, such as providing opportunities for renewal, retraining, and enrichment of personal abilities, increasing the cost-effectiveness of educational resources, supporting the quality and variety of existing educational structures, increasing skills, and other benefits of distance learning is its convenience because many technologies are easily accessed from home (Buselic, 2012).

The implementation of distance learning requires the role of technology and internet networks. In practice, distance learning during this pandemic can be carried out by using platforms such as Google Classroom, WhatsApp, or Zoom. Distance learning both online (innetwork / online), offline (outside network / offline), and blended learning is a mainstay for the government to continue providing educational services until the end of the 2019-2020 school year and the plan for the 2020-2021 school year also, distance learning is still being done to prevent Covid-19 transmission. However, the implementation of distance learning during the Covid-19 pandemic faces challenges and obstacles to the limitations of supporting facilities but also to the readiness of human resources, less productive government directives, and the lack of an appropriate distance learning curriculum (Arifa, 2020).

This was also reinforced by the decision of 4 ministries, the ministry of education and culture, the ministry of religion, the ministry of health, and the ministry of internal affairs regarding guidelines for organizing learning in the school year and the new academic year in the COVID-19 pandemic, issued on June 15, 2020. The decision said that for areas in the yellow, orange, and red zones are prohibited from doing face-to-face learning in education units. Early childhood education becomes the last level of education that may hold face-to-face learning, it means that one semester ahead ECE teachers must be prepared to undergo the process of distance learning. Because according to COVID-19 data as of June 15, 2020, 94\% of students are still in the yellow, orange, and red zones. This presents a major challenge for ECE teachers to improve their professional competence so that they can adapt to the conditions in the Covid-19 pandemic and answer the challenges in the era of society 5.0.

Based on the results of the 2018-2019 ECE statistics which include formal and non-formal both public and private PAUD teachers who have an undergraduate education qualification or more of $75,82 \%$ of the total number of 656.210 ECE teachers in Indonesia. (Education and Cultural Data and Statistics Center, 2019)

The consequence of distance learning during this pandemic is demanding the professional abilities of a teacher. Professional ECE teachers should know the competency standards that must be possessed. So that the main task of teachers in guiding, motivating and facilitating early childhood care and education activities can run optimally. The competencies that early childhood teachers must have include four competencies, namely pedagogic competence, social competence, professional competence and personality competence. Professional competence is considered important to be developed by teachers because it is 
directly related to the performance displayed, it is seen when how a teacher can present interesting learning for students.

Understanding of professional competence listed in government regulation No.19 of 2005 governing National Education Standards Chapter VI on Educators and Education Workforce Standards, Part One about Educators, Article 28 Paragraph 3, states that professional competence is the ability of educators in the mastery of the material broad and deep learning that allows it to guide students to obtain the specified competencies. Professional competence is the ability to master broad and deep learning material that enables it to guide children to meet the competency standards set in the National Education Standards (Saputri, 2019).

In the Regulation of the Minister of Education and Culture of the Republic of Indonesia number 137 of 2014 concerning the competency standards of Early Childhood Education teachers mentioning about professional competencies as follows: (1) Understanding the stages of child development, (2) Understanding the growth and development of children, (3) Understanding providing stimuli for education, care, and protection, (4) Building cooperation with parents in education, care, and protection of children, (5) Communicating effectively. Based on these descriptions it can be concluded that the professional competence of the teacher can be interpreted as an ability that must be possessed by a teacher as a provision in carrying out its main tasks in teaching. Professional assignments are sourced from the education and experience gained and master teaching material widely and deeply.

The information and communication technology (ICT) is important for teachers to master, especially for use in online learning. In the current digital era, mastery of ICT is necessary for everyone included teachers because many community activities use media or technological devices, including in the world of education. Almarzooq et al. (2020) said that learning that can be carried out during the Covid-19 pandemic must-have innovations and improvise with technological developments, namely being able to use several platforms that support online learning such as the zoom application, smartphone, WhatsApp group, google classroom. Teachers and students must be able to take advantage of the advantages of technology to attract students and make schools achieve excellence (Raja \& Nagasubramani, 2018).

Related to the importance of preparing future generations who have excellent character and ability to answer challenges in their time and this is inseparable from the role of a teacher, the researcher was interested to conduct a study entitled "The Impact of Distance Learning in the Covid-19 Pandemic Period in ECE Teacher Professional Competence".

\section{METHODOLOGY}

This research uses a descriptive qualitative approach. The approach was chosen because in this study it will describe and analyze research findings of the impact of distance learning on improving the professional competence of ECE teachers during the Covid-19 pandemic. This study involved 30 ECE teachers from three different provinces in Java. The research sample selection used a cluster sampling technique by producing three provinces DKI Jakarta, West Java, and Central Java Province. The research sample is ECE teachers' both formal and informal, and has diverse educational backgrounds. The mean age of the participants was $X^{-}=39.03$ years $(\mathrm{L}=3 ; \mathrm{W}=27)$. Table 1 below is the profile of respondents collected in this study.

Table 1. Respondent Data Profile

\begin{tabular}{|c|c|c|c|c|c|c|c|}
\hline Province & $\mathbf{n}$ & $\begin{array}{c}\text { Education } \\
\text { background }\end{array}$ & $\mathbf{n}$ & $\begin{array}{l}\text { Group } \\
\text { teaching }\end{array}$ & $\mathbf{n}$ & $\begin{array}{c}\text { Teaching } \\
\text { experience }\end{array}$ & $\mathbf{n}$ \\
\hline DKI Jakarta & 7 & Highschool & 3 & $3-4$ yo & 4 & $<1$ yo & 2 \\
\hline West Java & 16 & ECE undergraduate & 13 & $4-5$ yo & 12 & $1-5$ yo & 9 \\
\hline Central Java & 7 & Non ECE & 3 & $5-6$ yo & 14 & & \\
\hline & & $\begin{array}{c}\text { undergraduate } \\
\text { Continuing college }\end{array}$ & 11 & & & $\begin{array}{l}5-10 \text { yo } \\
>10 \text { yo }\end{array}$ & $\begin{array}{c}9 \\
10\end{array}$ \\
\hline
\end{tabular}


The study was conducted by distributing open questionnaires online via a google form. The google form link is distributed via Whatsapp to ECE teachers in the three selected provinces, DKI Jakarta, Central Java, and West Java. Data collection via google form is carried out for one month.

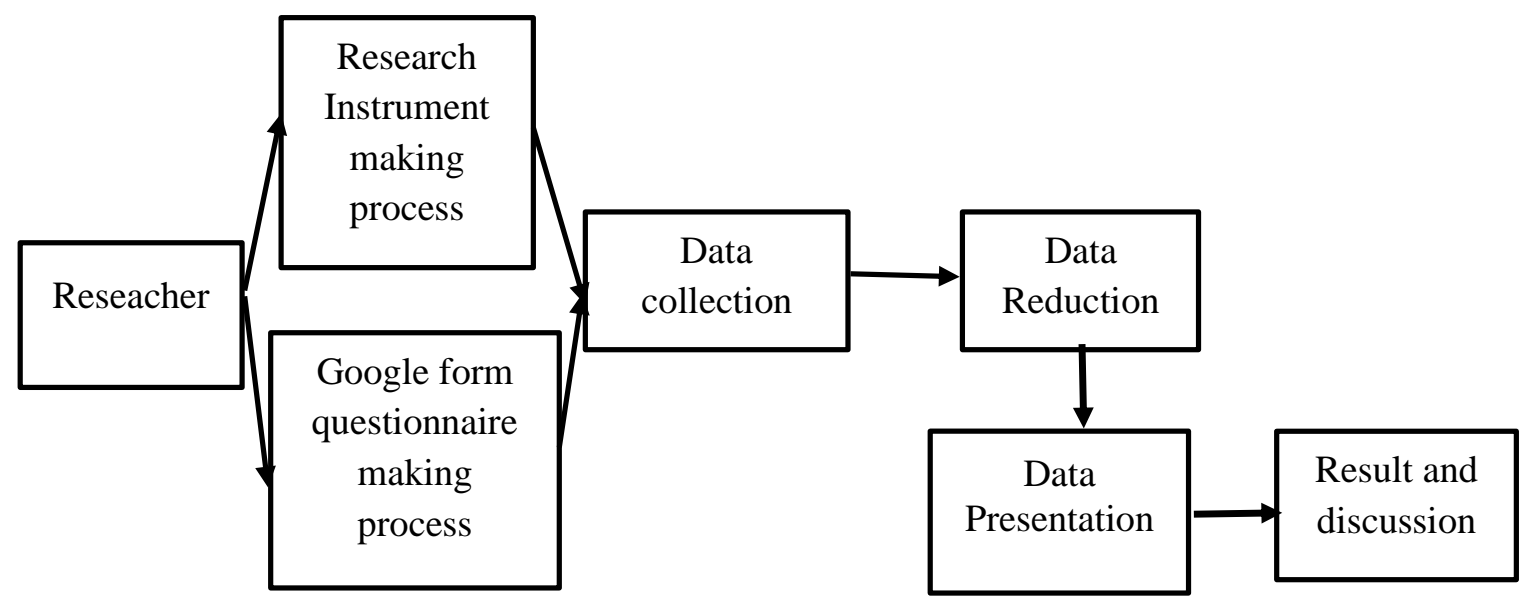

Picture 1. Scheme of The Research

The instruments in the form of an open questionnaire compiled participant profiles and research questions compiled based on theoretical studies that had been collected. The research questionnaire contained indicators of the professional competencies of ECE teachers: 1) Understand the growth and development of children, 2) Understand the provision of educational stimuli, protection, and care, and 3) Build cooperation and communication with parents. From the three indicators then the researcher developed it into 17 questions. The first indicator becomes 2 research questions, the second indicator becomes 8 research questions, and 7 research questions for the third indicator. The instruments that have been compiled are then validated using informant reviews, so that the researcher and informants have the same understanding as the data source. Then the data are analyzed by grouping participants' answers so that it becomes a meaningful result based on predetermined instrument indicators. The data analysis technique uses stages starting from data collection through research instruments distributed via google form, then the data is reduced to retrieve meaningful data. After that the meaningful data is presented to take the results and conclusions.

\section{RESULT AND DISCUSSION}

\section{Result}

Based on the results of our study of ECE teachers spread across three provinces namely DKI Jakarta, West Java, and Central Java, the impact of distance learning was identified on the professional competence of ECE teachers during the co-19 pandemic. The open questionnaire contained three indicators of ECE teacher professional competence that had been distributed via Google form to ECE teacher respondents. Data shows that the existence of distance learning programs during the pandemic COVID-19 had a very good effect on the professional competence of ECE teachers.

The results of the research that will be described include 3 indicators, namely (1) indicators of understanding of children's development (table 2), (2) indicators of understanding in providing stimulation of education and care (table 3), (3) indicators of the ability to build cooperation and communication with parents. and children (table 4). The results of the research on the indicators of understanding the growth and development of children the results as set out in table 1 below: 
The Impact of Distance Learning Implementation in Early Childhood Education Teacher Profesional Competence DOI: $10.31004 /$ obsesi.v5i2.1009

Table 2. Result of teachers' understand about the growth and ECD

\begin{tabular}{lcccccc}
\hline & result & n & result & n & result & n \\
\hline $\begin{array}{l}\text { The suitability of DL } \\
\text { plans and STPPA }\end{array}$ & Appropriate & 24 & doubt & 5 & Not appropriate & 1 \\
\hline $\begin{array}{l}\text { Teachers' understanding } \\
\text { of ECD }\end{array}$ & Well understand & 23 & $\begin{array}{c}\text { Not really } \\
\text { understand }\end{array}$ & 7 & \\
\hline
\end{tabular}

Professional competence is related to the mastery of teachers on early childhood development material as a substance, including physical-motor development, language, socialemotional, moral religion, and art. Distance learning program influences the mastery of aspects of professional competence on the ability to make learning plans that are in accordance with the STPPA (Child Development Achievement Level Standards). STPPA is a part of Indonesian National Curriculum of early childhood education. Most of the teachers (24 teachers) have adjusted their distance learning plans according to the STTPA, one teacher said that it was not appropriate and five others were still in doubt. This was achieved because it was supported by the ability of teachers to understand the level of achievement of good child development.

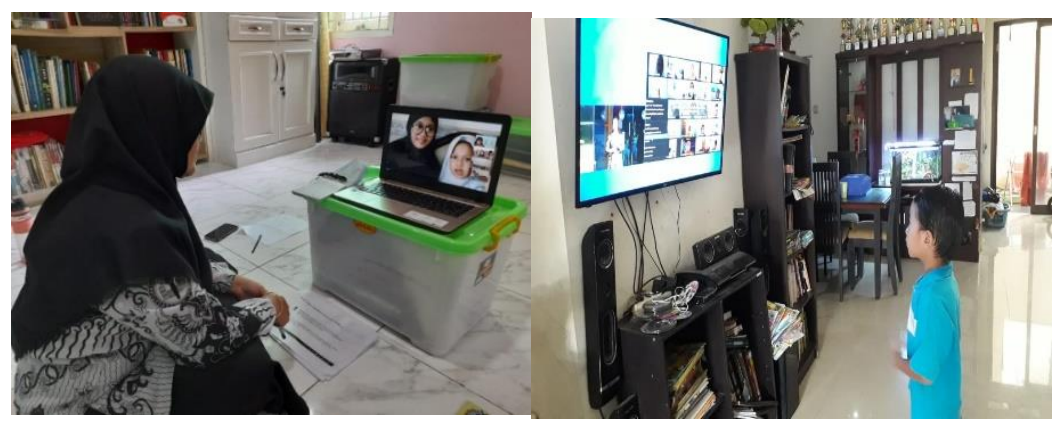

Picture 2. Process to understanding the growth and development of children

Based on the results analyzed that as many as 23 teachers already have a good understanding of the level of achievement of child development, five teachers can explain quite well and two teachers have not been able to explain the urgency of the level of achievement of child development correctly. The data shows that the teacher has been able to integrate his knowledge of the level of achievement of children's development by making learning plans that refer to STTPA.

The results of research related to understanding the provision of educational stimulations, protection, and care that of teacher data analysis ( 27 people) can explain well that the learning plan must be arranged according to the stages of age so that the stimulation provided is in accordance with the child's ability. This is done so that children can get the right portion so that their development can run optimally. Only a small portion (3) teachers who have not been able to explain it correctly.
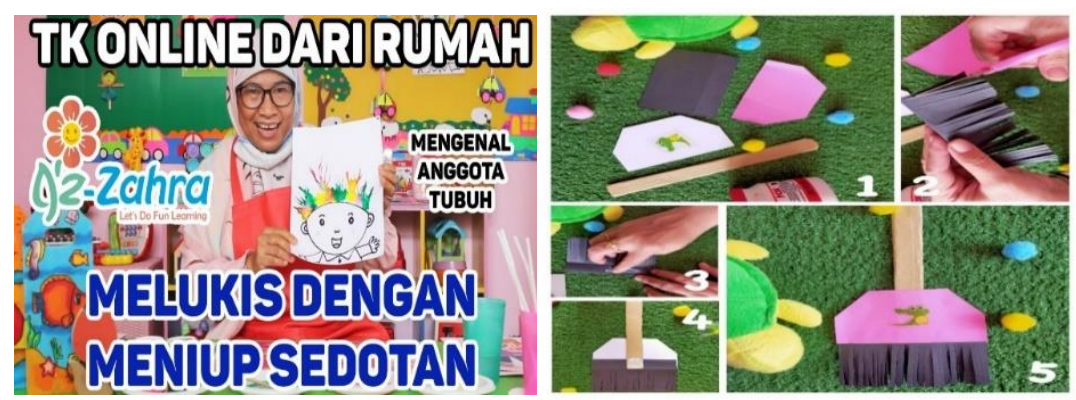

Picture 3. Process to nderstanding the provision of educational stimulations, protection, and care. 
In the practice of implementing distance learning, teachers also face various obstacles and constraints, ten teachers explained because of the limited gadget or not all children have facilities that are eligible to implement distance learning. Whereas 18 teachers stated that distance learning made learning goals not biased well, one teacher revealed that the constraints of distance learning were salaries that were not paid, and one teacher explained that the distance that approached distance learning was well implemented.

These obstacles and constraints make it possible that learning outcomes or assignments were given to children do not match what the teacher expected. This makes the teacher must determine an alternative attitude. Ten teachers expressed tolerance and understanding of children's work, and 20 teachers provided solutions in the form of other learning methods that were more enjoyable so that children remained happy and could fulfill their development.

Forms of care and attachments made by teachers during distance learning are also carried out to support learning. The form of care is by checking the health of the child during distance learning. As many as eleven teachers have carried out these activities so that health information about children can be well recorded between teachers and parents. While 19 teachers have not yet carried out the process.

Implementation of distance learning that is different from the face-to-face method makes the teacher feel the difference in the achievement of aspects of child development. Most (19 people) explained that the evaluation process during distance learning was more difficult than when face-to-face, eight teachers stated that with the distance learning mentoring or attachment of teachers to children was less than optimal, the activeness of children also became the affected side because of distance learning, this was explained by two teachers. While one teacher explained about the pressure felt more by children with distance learning.

However, with distance learning, the teacher has made various learning innovations that are manifested in the material or media, with the aim of making distance learning more interesting for children to follow. The data result showed that 27 teachers have made innovations in learning, while 3 teachers haven't.

It is expected that in the implementation of distance learning all children can follow it. However, due to the limitations of alternative facilities conducted by teachers so that all children can receive learning is to do a home visit (26 teachers), while four teachers still hold distance learning with existing facilities.

Other efforts made by the teacher so that all children can receive stimulation during distance learning are by establishing good communication with parents during a home visit (15 teachers) or through WhatsApp group (12 teachers) and providing consultation and sharing (3 teachers).

The results of research related to Building cooperation and communication with parents that he professional competency indicator in this section shows that respondents have a good understanding of the factors that support and hinder children's development. The results of the teacher data analysis in this study reveal the economic background of the students. Three teachers explained that on average their students came from upper economies, 17 teachers provided information that their students came from the middle economy, while 10 teachers stated that their students came from the lower economy.

But even in a COVID-19 pandemic situation learning must continue. Teachers are still trying to build positive communication with parents in terms of delivering ECE programs both related to learning and nurturing and protection despite the limitations of existing conditions. The communication that was carried out also varied, the results of the analysis of the teacher's data obtained (14 people) chose through social media in the form of WhatsApp group, video call, and zoom. 12 people chose by direct face-to-face or home visits, and 4 teachers used both methods.

Based on data from 30 teachers, all parents are involved in accompanying their children during the implementation of distance learning. The efforts made by teachers to improve competence in order to be able to take part in the distance learning system in the era of the 
The Impact of Distance Learning Implementation in Early Childhood Education Teacher Profesional Competence DOI: $10.31004 /$ obsesi.v5i2.1009

industrial revolution 4.0 were 10 teachers participating in webinars, 6 teachers learning through tutorials via Youtube, 6 teachers conducting discussions with peers, and 8 others made all these efforts.

Table 3. Result of teachers understand the provision of educational stimulations, protection and care.

\begin{tabular}{|c|c|c|c|c|c|c|c|c|}
\hline & result & $\mathbf{n}$ & result & $\mathbf{n}$ & result & $\mathbf{n}$ & result & n \\
\hline $\begin{array}{l}\text { Teachers' } \\
\text { understanding to align } \\
\text { DL plans with ECD } \\
\text { levels }\end{array}$ & $\begin{array}{c}\text { Well } \\
\text { understand }\end{array}$ & 27 & $\begin{array}{l}\text { Not really } \\
\text { understand }\end{array}$ & 3 & & & & \\
\hline $\begin{array}{l}\text { Teachers' obstacles } \\
\text { and constraints }\end{array}$ & $\begin{array}{c}\text { limited } \\
\text { gadget and } \\
\text { facilities }\end{array}$ & 10 & $\begin{array}{l}\text { Learning } \\
\text { goals aren't } \\
\text { achieved }\end{array}$ & $\begin{array}{l}1 \\
8\end{array}$ & No salary & 1 & distance & 1 \\
\hline $\begin{array}{l}\text { Teachers responses to } \\
\text { children's learning } \\
\text { outcomes that are not } \\
\text { appropriate }\end{array}$ & $\begin{array}{l}\text { provide } \\
\text { tolerance }\end{array}$ & 10 & $\begin{array}{l}\text { provided } \\
\text { alternative } \\
\text { solutions }\end{array}$ & $\begin{array}{l}2 \\
0\end{array}$ & & & & \\
\hline $\begin{array}{l}\text { Checking the health of } \\
\text { the child during } \\
\text { distance learning }\end{array}$ & did & 11 & didn't & $\begin{array}{l}1 \\
9\end{array}$ & & & & \\
\hline $\begin{array}{l}\text { The difference that } \\
\text { teachers felt in the } \\
\text { achievement of } \\
\text { aspects of child } \\
\text { development }\end{array}$ & $\begin{array}{l}\text { evaluation } \\
\text { procces }\end{array}$ & 19 & $\begin{array}{l}\text { mentoring } \\
\text { or } \\
\text { attachment }\end{array}$ & 8 & $\begin{array}{l}\text { Children } \\
\text { activeness }\end{array}$ & 2 & pressure & 1 \\
\hline $\begin{array}{l}\text { Innovation in media } \\
\text { and materials }\end{array}$ & did & 27 & didn't & 3 & & & & \\
\hline $\begin{array}{l}\text { The way teachers } \\
\text { respond to limited } \\
\text { facilities }\end{array}$ & home visit & 26 & $\begin{array}{l}\text { distance } \\
\text { learning }\end{array}$ & 4 & & & & \\
\hline $\begin{array}{l}\text { the teacher's efforts to } \\
\text { stimulate all children } \\
\text { during DL }\end{array}$ & $\begin{array}{l}\text { WhatsApp } \\
\text { Group }\end{array}$ & 12 & Home visit & $\begin{array}{l}1 \\
5\end{array}$ & $\begin{array}{c}\text { Combine } \\
\text { (offline and } \\
\text { online } \\
\text { learning, } \\
\text { consultatio } \\
\text { n and } \\
\text { sharing) }\end{array}$ & 3 & & \\
\hline
\end{tabular}
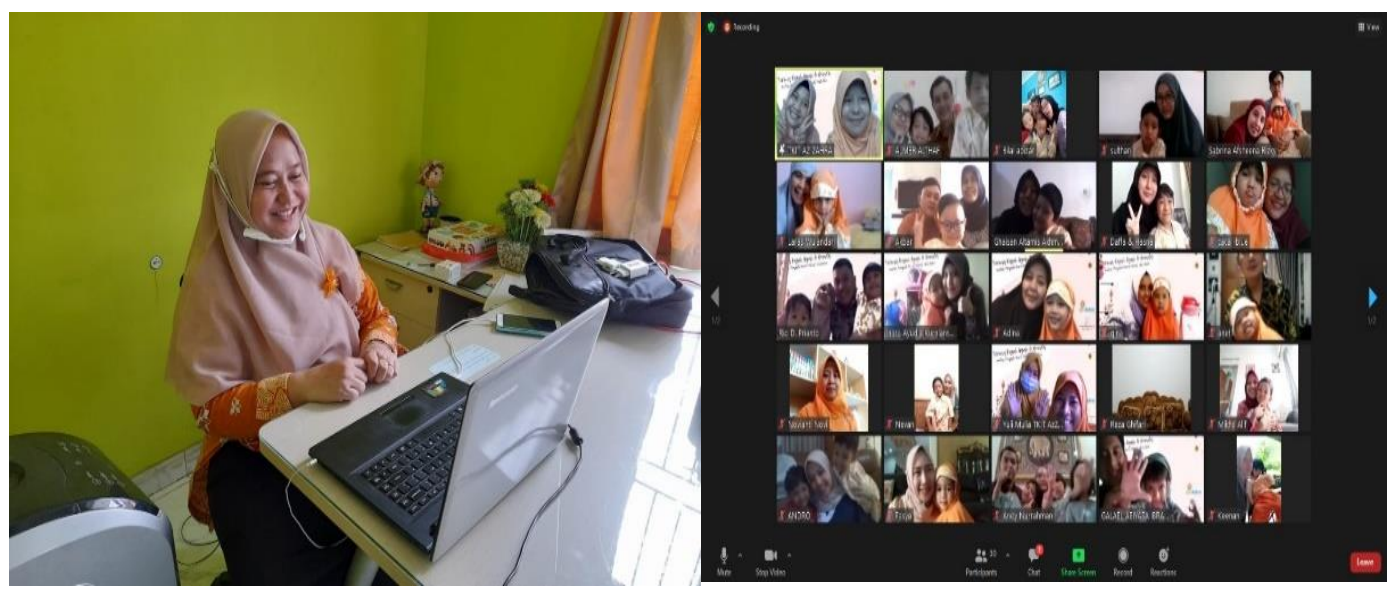

Picture 4. Process to Building cooperation and communication with parents. 
The solution that must be done so that distance learning at the ECE level can be felt by all society according to the teacher is free internet access (7 teachers), teacher training (20 teachers), and others (3 teachers). Furthermore, based on data from 30 teachers, it was stated that all teachers provide opportunities for parents to consult regarding obstacles faced during distance learning. The communication made by the teacher to the child to find out the response to distance learning is carried out in various time periods. 15 teachers carry out communication every day, seven teachers out communication twice, and four teachers carry out a communication once a week. This had an impact on the parents' positive response to the implementation of distance learning during this co-19 pandemic condition. so that this becomes an encouragement for ECE teachers also in designing distance learning for their students.

Distance learning that has been going on for 5 months (March-August) also has a positive impact on the ability of teachers in mastering technology, such as the ability to use computers in learning activities and assisting administrative tasks of teachers such as processing grades and limiting learning designs. The ability to use the internet as a communication tool such as WAG, zoom, chat and use of social networking sites, also the internet as an information retrieval tool such as; browsing, downloading, youtube learning tutorials, and others. The ability to use IT devices as learning media such as; making media presentations with PowerPoint, making digital teaching materials, making learning videos, and others.

Table 4. Result of teacher building cooperation and communication with parents.

\begin{tabular}{|c|c|c|c|c|c|c|c|c|}
\hline & result & $\mathbf{n}$ & result & $\mathbf{n}$ & result & $\mathbf{n}$ & result & $\mathrm{n}$ \\
\hline $\begin{array}{l}\text { Student economic } \\
\text { status }\end{array}$ & $\mathrm{Up}$ & 3 & middle & 17 & low & 10 & & \\
\hline $\begin{array}{l}\text { Teacher-parents } \\
\text { communication } \\
\text { methode }\end{array}$ & $\begin{array}{l}\text { WhatsA } \\
\text { pp, } \\
\text { Zoom } \\
\text { etc }\end{array}$ & 14 & $\begin{array}{l}\text { Face-to } \\
\text { face, home } \\
\text { visit }\end{array}$ & 12 & $\begin{array}{l}\text { Both } \\
\text { medthode }\end{array}$ & 4 & & \\
\hline Parents involving & All & 30 & & & & & & \\
\hline $\begin{array}{l}\text { Teacher effort to } \\
\text { improve their } \\
\text { competencies }\end{array}$ & Webinar & 10 & $\begin{array}{l}\text { Youtube } \\
\text { tutorial }\end{array}$ & 6 & $\begin{array}{l}\text { Sharing with } \\
\text { peers }\end{array}$ & 6 & $\begin{array}{l}\text { Used all } \\
\text { effort }\end{array}$ & 8 \\
\hline Expecting solution & $\begin{array}{l}\text { Free } \\
\text { internet } \\
\text { access }\end{array}$ & 7 & $\begin{array}{l}\text { Teacher } \\
\text { training }\end{array}$ & 30 & others & 3 & & \\
\hline $\begin{array}{l}\text { Consultation } \\
\text { opportunities }\end{array}$ & All & 30 & & & & & & \\
\hline $\begin{array}{l}\text { Teacher-parents } \\
\text { communication } \\
\text { about child's respon }\end{array}$ & $\begin{array}{l}\text { everyda } \\
y\end{array}$ & 15 & $\begin{array}{l}\text { Three } \\
\text { times a } \\
\text { week }\end{array}$ & 7 & Twice a week & 4 & $\begin{array}{l}\text { Once a } \\
\text { week }\end{array}$ & 4 \\
\hline
\end{tabular}

\section{Discussion}

The study result ECE showed that teachers play a role in the success of children's development. Phajane (2014) also revealed that ECE teachers had a role and responsibility, including in providing care and childcare, facilitating children's learning, observing and assessing children's development and professional advocacy. As the demand for education quality increases, ECE teachers must improve their competencies. As explained that teacher competence to improve the learning process becomes very important (Selvi, 2010). Based on the results of the study showed that ECE teachers were able to improve their professional competence in implementing distance learning especially on their on their skills to using technologies. This was closely related to the demands of teachers during a pandemic that must involve technology in their learning process. Teachers 'competence in the field of information technology follow to research by Tambunan (2014) was influenced by the teacher's interpersonal communication, use of information technology tools, teachers' perceptions toward information technology, and self-improvement of teachers either directly or indirectly. 
The results of this study indicate an increase in the skills of ECE teachers in using technology both in the preparation, learning process and learning evaluation during distance learning. Whereas before distance learning was implementes or in face-to-face learning described by (Febrialismanto \& Nur, 2020) the mastery of ICT in ECE teachers was still low. The use of technology is part of the innovations made by teachers in PAUD learning. During distance learning, the teacher created various material innovations and learning media to meet the stimulation given to children. According to (Ertmer et al., 2012) also mentioned that teacher determined computer systems specifically beneficial due to the fact they: 1) deliver content andreinforce skills, 2) complement or enrich the curriculum, and 3) transform teaching by experiment-ing, implementing, and refining new approaches. Innovations made by teachers explained had a positive effect on students who have diverse circumstances (Naz \& Murad, 2017). Kovacs (2017) also stated the need for technological innovation to encourage further learning in order to get better results for schools, students, and society in the future.

As data in the field that children who take distance learning have various facilities. During the implementation of distance learning, the teacher needs the role of parents as a child supervisor at home. This requires the teacher to establish effective relationships and communication with parents to optimize cooperation in providing appropriate stimulation to children. Teachers and parents are required to use technology, namely by communicating actively during distance learning using smartphones as a digital communication tools. Thompson et al. (2015) revealed that smartphones have influenced the way parents and teachers communicate, suggesting that parents view academic support and new communication technologies as essential to their child's education. A studi from Kaptich et al., (2019) also showed that relationships and communication that are well established between teachers and parents are known to have a positive effect on children's academic achievement. Other research from Erdreich (2020) suggests that parent-teacher digital communication is an important component of schooling which can direct and form the intimate ties through which 'proper' parenting is defined.

\section{CONCLUSIONS}

Covid-19 pandemic has an impact on education, including early childhood education. This presents a major challenge for Early Childhood Education educators to improve their professional competence so that they can adapt to conditions in the current Covid-19 pandemic and respond to challenges in the era of society 5.0. The purpose of this study was to analyze the impact of distance learning on ECE teachers' professional competencies. Sampling used cluster sampling techniques. This study involved 30 ECE teachers from four provinces on the island of Java (DKI Jakarta, West Java, and Central Java), each province had ten teachers. The method used in this research is descriptive qualitative. Data collection techniques used open questionnaires containing indicators of ECE teacher's professional competencies, namely an understanding of children's growth and development, understanding in providing educational and nurturing stimulation, and the ability to build cooperation and communication with parents and children.

\section{ACKNOWLEDGMENT}

We gratefully acknowledge the support given by the Early Childhood Education Program of IKIP Siliwangi.

\section{REFERENCES}

Almarzooq, Z. I., Lopes, M., \& Kochar, A. (2020). Virtual Learning During the COVID-19 Pandemic: A Disruptive Technology in Graduate Medical Education. Journal of the American College of Cardiology, 75(20), 2635-2638. https:// doi.org/10.1016/j.jacc.2020.04.015 
Arifa, F. N. (2020). Tantangan Pelaksanaan Kebijakan Belajar Dari Rumah Dalam Masa Darurat Covid-19. Info Singkat;Kajian Singkat Terhadap Isu Aktual Dan Strategis, XII(7/I), 6. http://berkas.dpr.go.id/puslit/files/info_singkat/Info Singkat-XII-7-I-P3DI-April-20201953.pdf

Buselic, M. (2012). Distance Learning - concepts and contributions. Oeconomica Jadertina, 1, 2334. https:/ / doi.org/ISSN 1848-1035

Casarotti, M., Filipponi, L., Pieti, L., \& Sartori, R. (2002). Educational interaction in distance learning: Analysis of a one-way video and two-way audio system. PsychNology Journal, $1(1), 28-38$.

Erdreich, L. (2020). Mediating intimacy: parent-teacher digital communication and perceptions of 'proper intimacy' among early childhood educators. International Studies in Sociology of Education, 00(00), 1-21. https:/ / doi.org/10.1080/09620214.2020.1807387

Ertmer, P. A., Ottenbreit-Leftwich, A. T., Sadik, O., Sendurur, E., \& Sendurur, P. (2012). Teacher beliefs and technology integration practices: A critical relationship. Computers and Education, 59(2), 423-435. https://doi.org/10.1016/j.compedu.2012.02.001

Fathoni, T., Sukirman, D., \& Riyana, C. (2016). Program Pendidikan Jarak Jauh Berbasis ICT dan Penguasaan Kompetensi Guru. Jurnal Penelitian Pendidikan, ISSN 1412-565, 182-195.

Febrialismanto, F., \& Nur, H. (2020). Kemampuan Guru Menggunakan TIK Untuk Pengembangan di Taman Kanak-Kanak. KINDERGARTEN: Journal of Islamic Early Childhood Education, 2(2), 101. https:/ / doi.org/10.24014/kjiece.v2i2.8296

Jajat Sudrajat. (2020). Kompetensi Guru di Masa Pandemi Covid-19. Jurnal Riset Ekonomi dan Bisnis, 13(1), 106. https://doi.org/http://dx.doi.org/10.26623/jreb.v13i2.2434

Kaplan, A. M., \& Haenlein, M. (2016). Higher education and the digital revolution: About MOOCs, SPOCs, social media, and the Cookie Monster. Business Horizons, 59(4), 441-450. https://doi.org/10.1016/j.bushor.2016.03.008

Kaptich, P., Kiplangat, H. K., \& Munyua, J. (2019). Influence of parent-teacher communication on academic performance of pupils in public primary schools in Ainabkoi sub-county, Kenya. Universal Journal of Educational Research, 7(6), 1356-1362. https://doi.org/10.13189/ujer.2019.070603

Kovacs, H. (2017). Learning and Teaching in Innovation: why it is important for education in 21st century. Neveléstudomány, 5(2), 45-60. https:// doi.org/10.21549/ntny.18.2017.2.4

Naz, F., \& Murad, H. S. (2017). Innovative teaching has a positive impact on the performance of diverse students. SAGE Open, 7(4). https://doi.org/10.1177/2158244017734022

Phajane, M. H. (2014). Exploring the roles and responsibilities of early childhood teachers. Mediterranean Journal of Social Sciences, 5(10 SPEC. ISSUE), 420-424. https://doi.org/10.5901/mjss.2014.v5n10p420

Pusat Data dan Statistik Pendidikan dan Kebudayaan. (2019). Statistik PAUD 2018/2019.

Raja, R., \& Nagasubramani, P. C. (2018). Impact of modern technology in education. Journal of Applied and Advanced Research, 3(S1), 33. https://doi.org/10.21839/jaar.2018.v3is1.165

Sadeghi, M. (2019). Manijeh Sadeghi 1. Internasional Journal of Reserach in Englissh (IJREE), March, 80-88. https://doi.org/http://dx.doi.org/10.29252/ijree.4.1.80

Saputri, P. M. (2019). Kompetensi Profesional Guru PAUD Dalam Proses Pembelajaran Anak Usia Dini Pada TK Al-Khairiyah Kecamatan Sidomulyo Kabupaten Lampung Selatan. In Duke Law Journal (Vol. 1, Nomor 1).

Selvi, K. (2010). Teachers ' Competencies. VII(1), 167-176.

Tambunan, H. (2014). Factors affecting teachers' competence in the field of information $\begin{array}{lllll}\text { technology. International } & \text { Education }\end{array}$ https://doi.org/10.5539/ies.v7n12p70

Thompson, B. C., Mazer, J. P., \& Flood Grady, E. (2015). The Changing Nature of Parent-Teacher Communication: Mode Selection in the Smartphone Era. Communication Education, 64(2), 187-207. https://doi.org/10.1080/03634523.2015.1014382 